\title{
A REVIEW ON TABERNAEMONTANA SPP.: MULTIPOTENTIAL MEDICINAL PLANT
}

\author{
ANAN ATHIPORNCHAI* \\ Department of Chemistry and Center of Excellence for Innovation in Chemistry, Faculty of Science, Burapha University, Bangsaen, \\ Chonburi 20131 Thailand. Email: anana@buu.ac.th
}

Received: 01 March 2016, Revised and Accepted: 29 January 2018

\section{ABSTRACT}

Plants in the genus Tabernaemontana have been using in Thai and Chinese traditional medicine for the treatment several diseases. The great majority constituents of Tabernaemontana species have already been subjected to isolation and identification of monoterpene indole alkaloids present in their several parts. Many of monoterpene indole alkaloids exhibited a wide array of several activities. The biogenesis, classification, and biological activities of these alkaloids which found in Tabernaemontana plants were discussed in this review and its brings the research up-to-date on the bioactive compounds produced by Tabernaemontana species, directly or indirectly related to human health.

Keywords: Tabernaemontana plants, Phytochemistry, Biogenesis, Terpene indole alkaloids, Biological activities.

(c) 2018 The Authors. Published by Innovare Academic Sciences Pvt Ltd. This is an open access article under the CC BY license (http://creativecommons. org/licenses/by/4. 0/) DOI: http://dx.doi.org/10.22159/ajpcr.2018.v11i5.11478

\section{INTRODUCTION}

Several already drugs were discovered from the natural products. Especially, the treatments of infectious diseases and oncology have benefited from numerous drugs which were found in natural product sources. Some of new and interesting natural compounds with biological activities have been published in the past few years. The potent biological activities, no side effects, and economic viability of medicinal properties from natural products have been investigated in the recent scientific developments worldwide. Bioactive compounds from medicinal plants showed pharmacological or toxicological effects in man and animals. The typical bioactive compounds are secondary metabolites including steroids, glycosides, phenolics, tannins, anthocyanins, flavonoids, and alkaloids. The basic structural of alkaloids are nitrogen-containing compounds. The several properties of alkaloids are bitter taste and usually with potent biological activities. Moreover, these secondary metabolites have diverse clinical biological properties [1-3]. Name of the genus Tabernaemontana is the birthplace (Tabermaemontanus) of J. Th. Miller, a German physician and botanist who was born in Bergzabern and died in Heidelberg in the Pfalz in 1590. The genus of Tabernaemontana belonging to the Apocynaceae family and composing about 100 species distributed throughout the tropical and some subtropical parts of the world. Many of plants in the Tabernaemontana species are used in traditional medicine and for other purposes for the treatment of sore throat, hypertension, and abdominal pain [4-6]. Plants of Tabernaemontana genus are a prolific source of the monoterpene indole alkaloids and they have been shown to produce many skeletal types such as secotabersonine alkaloids, bisvobtusine-type alkaloids, and bis-vobasinyl-ibogan indole alkaloids [79]. These alkaloids are a diverse class of natural products, comprising over 2000 members and possess a range of chemical structures and a wealth of biological activities such as anticancer, antimalarial, and antiarrhythmic agents [10]. Therefore, the biogenesis, classification, and biological activities of the indole alkaloids found in Tabernaemontana species were discussed in this review and its bring the research upto-date on the bioactive compounds produced by Tabernaemontana species, directly or indirectly related to human health.

Classification and biogenesis of monoterpene indole alkaloids Many skeletal types of monoterpene indole alkaloids from Tabernaemontana plants were exhibited a wide array of biological activities. Then, the biosynthetic pathways of some classes of these alkaloids are investigated. All monoterpene indole alkaloids are derived from aromatic amino acid tryptophan and the iridoid terpene secologanin (Scheme 1). Tryptophan converts to tryptamine using tryptophan decarboxylase which is a pyridoxal-dependent enzyme. The specific iridoid precursor was subsequently identified as secologanin. After that, tryptamine was reacted with the secologanin using the enzyme strictosidine synthase catalyzes a stereoselective Pictet-Spengler condensation to yield strictosidine (iso-vincoside) ( $S$ stereochemistry at $\mathrm{C}$, Scheme 1 ), and this step is utilized in the first committed step of monoterpene indole alkaloid biosynthesis. The Rubiaceae, Nyssaceae, Loganiaceae, and Apocynaceae families of medicinal plants each produce monoterpene indole alkaloids with dramatically diverse structures. The mechanisms and control of the processes by which strictosidine rearranges into these diverse families of products remain one of the most fascinating problems in secondary metabolism [10].

The biosynthesis pathway of strictosidine rearranges also use as a basis for the classification of the monoterpene indole alkaloids occurring in the genus Tabernaemontana. Eleven classes of these alkaloids were reported to the structural characteristics of their skeletons including (1) vincosan, (2) corynanthean, (3) vallesiachotaman, (4) strychnan, (5) aspidospermatan, (6) plumeran, (7) eburnan, (8) ibogan, (9) tacaman, (10) bis-indole alkaloids, and (11) miscellaneous. The classification of the monoterpene indole alkaloids occurring in the genus Tabernaemontana were shown in Table 1 and Scheme $2[4,10]$.

\section{Bioactive compounds from the genus Tabernaemontana}

The plants of genus Tabernaemontana have been used in traditional medicine for the treatment of sore throat, hypertension, and abdominal pain [6]. The chemical constituents from several parts of the Tabernaemontana species were reported as monoterpene indole alkaloid compounds, and these compounds were shown to exhibit a wide array of biological activities including anticancer, antimalarial, and anti-arrhythmic agents [10]. This review brings the research upto-date on the bioactive compounds produced by Tabernaemontana species, directly, or indirectly related to human health.

\section{Tabernaemontana australis (Müell. Arg) Miers}

Andrade et al. reported the isolation and identification of ten indole alkaloids including coronaridine (1), voacangine (2), voacangine hydroxyindolenine (3), rupicoline (4), ibogamine (5), 
ibogaine (6), ibogaline (7), desethyl-voacangine (8), voachalotine (9), and affinisine (10) from the chloroform extract of stalk of T. australis (Müell. Arg) Miers by gas chromatography-mass spectrometry (GCMS) (Scheme 3). Some of them showed qualitative anticholinesterase activity using thin-layer chromatography assay and physostigmine and galanthamine were used as positive drugs [11].

\section{Tabernaemontana catharinensis A. DC}

In 2007, Soares et al. reported the extraction of branches and leaves of $T$. catharinensis by supercritical fluid using a mixture of $\mathrm{CO}_{2}$ plus ethanol (supercritical fluid extraction). It was found that the enrich

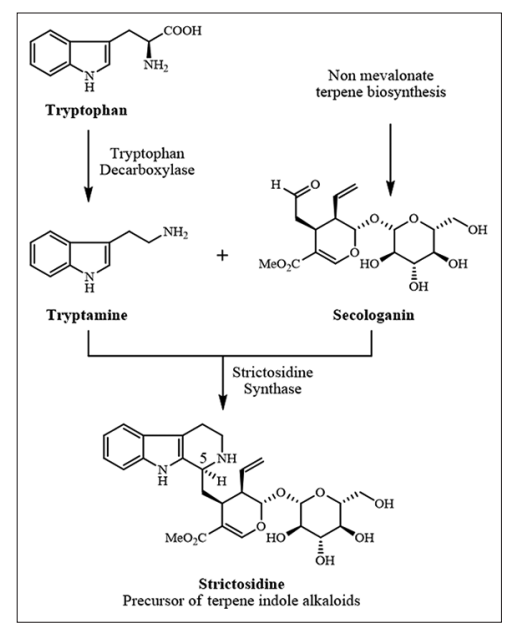

Scheme 1: First steps biosynthesis pathway of terpene indole alkaloids

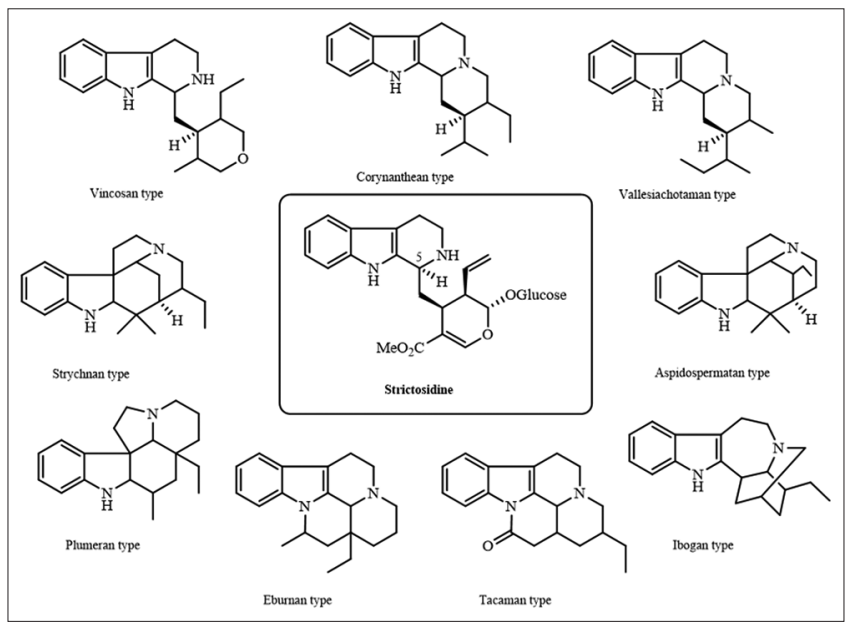

Scheme 2: Major classes of terpene indole alkaloids derived from strictosidine isolated from Tabernaemontana plants indole alkaloid fraction was showed a strong active against Leishmania amazonensis (leishmaniasis). Moreover, this fraction was inhibited NO production induced by IFN- $\gamma$ plus lipopolysaccharide which some of effect for antiparasite activity and they showed no cytotoxicity with host cells [12].

In 2013, Boligon et al. reported that the leaves extracts of T. catharinensis were evaluated total phenolic, flavonoid, tannin, and alkaloid contents. In addition, this extract was tested the antioxidant activities using 2,2-diphenyl-1-picrylhydrazyl free radical and thiobarbituric acidreactive species methods. From these results, the ethyl acetate (EA) fraction of leaves extract was the most effective fraction against two reactive species and showed high total phenols, flavonoids, tannins, and alkaloids contents. The results indicate that the leaves extracts of T. catharinensis has antioxidant potential and can be a promising source of natural antioxidants [2].

In 2015, the same group reported that the crude extracts, fractions, and subfractions of T. catharinensis were evaluated antimycobacterial, antimicrobial, and antiviral activities. The dichloromethane and butanolic fractions showed strong active against Enterococcus faecalis, Micrococcus sp., Staphylococcus aureus, and Bacillus subtilis with minimum inhibitory concentration (MIC) values of $31.25-1000 \mu \mathrm{g} / \mathrm{mL}$. Considering the Gram-negative bacteria, only butanolic fraction was effective against Proteus mirabilis and Aeromonas sp. (MIC $=62.5 \mu \mathrm{g} / \mathrm{mL}$ and $250 \mu \mathrm{g} / \mathrm{mL}$, respectively). In addition, the fungi Candida albicans, Candida glabrata, Cryptococcus neoformans, Saccharomyces cerevisiae, Aspergillus flavus, and Aspergillus fumigatus were particularly vulnerable for dichloromethane fraction (MIC=31.25-1000 $\mu \mathrm{g} / \mathrm{mL}$ ). The fractions and subfractions were effective against Mycobacterium smegmatis (MIC=19.53-156.25 $\mu \mathrm{g} / \mathrm{mL}$ ). Dichloromethane (selectivity index-SI=77.92), EA (SI=40.27) and NB (SI=28.97) fractions from the leaves exhibited a potential antiviral activity toward Herpes Simplex Virus Type 1 whereas dichloromethane subfraction from the leaves ( $\mathrm{SI}=12.28)$ and alkaloidal fraction (10.71) maintained this good activity. From these result studies were obtained T. catharinensis as a source for new antiviral and antimicrobial therapy [13].

\section{Tabernaemontana citrifolia Linn.}

In 2010, Marie-Magdeleine et al. reported that three extracts (aqueous, methanolic, and dichloromethane) of T. citrifolia fruits, leaves, and root were evaluated in vitro effect against Haemonchus contortus on four developmental stages of the parasite including egg hatch, larval development, L3 migration, and adult worm motility. From the results, the different parts of $T$. citrifolia showed significant effects with differences depending on the parasitic stage such as efficacies on the larval development stage for fruits extract. These results suggest that $T$. citrifolia will be to possess anthelmintic activity against $H$. contortus [14]

\section{Tabernaemontana coronaria (L) R. Br.}

In 2012, Poornima et al. evaluated that the acute and subacute toxicological of ethanol extract from T. coronaria. The ethanol extract showed no significant effect on hematology lipid and renal profiles and showed only a slight increase in alkaline phosphatase (ALP) and

Table 1: Classification of the terpene indole alkaloids from the genus Tabernaemontana

\begin{tabular}{lll}
\hline Class & Abbreviation & Structure characteristics \\
\hline Vincosan & D & C (2)-C (3)-C (14) unit, no N (4)-C (17) or N (4)-C (21) bond \\
Corynanthean & C & C (2)-C (3)-C (14) unit, N (4)-C (21) bond \\
Vallesiachotaman & V & C (2)-C (3)-C (14) unit, N (4)-C (17) bond \\
Strychnan & S & C (2)-C (16)-C (15) unit, C (3)-C (7) bond \\
Aspidospermatan & A & C (2)-C (16)-C (15) unit, no C (3)-C (7) bond \\
Plumeran & P & C (2)-C (16)-C (17)-C (20) unit \\
Eburnan & E & N (1)-C (16)-C (17)-C (20) unit \\
Tacaman & T & N (1)-C (16)-C (17)-C (14) unit \\
Ibogan & I & C (2)-C (16)-C (17)-C (14) unit \\
Bis-indole & B & Two indole alkaloids attached to each other \\
\hline
\end{tabular}




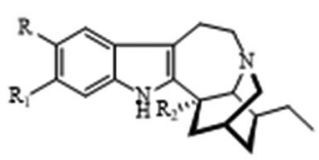

(1) Coronaridine: $\mathrm{R}=\mathrm{R}_{1}=\mathrm{H} ; \mathrm{R}_{2}=\mathrm{CO}_{2} \mathrm{CH}_{3}$

(2) Voacangine: $\mathrm{R}=\mathrm{H} ; \mathrm{R}_{1}=\mathrm{OCH}_{3} ; \mathrm{R}_{2}=\mathrm{CO}_{2} \mathrm{CH}_{3}$

(5) Ibogamine: $\quad \mathrm{R}=\mathrm{R}_{1}=\mathrm{R}_{2}=\mathrm{H}$

(6) Ilogaine: $\quad \mathrm{R}=\mathrm{OCH}_{3} ; \mathrm{R}_{1}=\mathrm{R}_{2}=\mathrm{H}$

(7) Ibogaline: $\quad \mathrm{R}=\mathrm{R}_{1}=\mathrm{OCH}_{3} ; \mathrm{R}_{2}=\mathrm{H}$

(8) Desethyl-roacangine: $\mathrm{R}=\mathrm{H} ; \mathrm{R}_{1}=\mathrm{OCH}_{3} ; \mathrm{R}_{2}=\mathrm{CO}_{2} \mathrm{CH}_{3}$
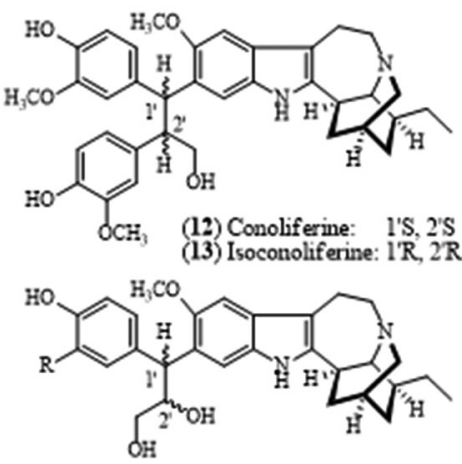

(14) Conomicidine A: (l'S, 2'S), $\mathrm{R}=\mathrm{OCH}_{3}$ (15) Conomicidine $\mathrm{B}$ : ( $\mathrm{l} \mathrm{R}, 2 \mathrm{R}), \mathrm{R}=\mathrm{OCH}_{3}$ (16) Isoconomicidine A: (l'S, 2'S), R=H (17) Isoconomicidine $B:\left(I^{\prime} R, 2 R\right), R=H$<smiles>[R4]Oc1cc2c(cc1OC)NC1=C(C(=O)OC)C[C@@]3(CC)C=CC([R4])=NN3CC[C@@]12C</smiles>

(25) Jerantinine $A: \mathrm{R}_{1}=\mathrm{H}_{2}, \mathrm{R}_{2}=\mathrm{H}$ (27) Jerantinine C: $R_{1}=O, R_{2}=H$

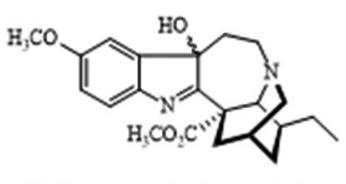

(3) Voacangine hydroxyindolenine

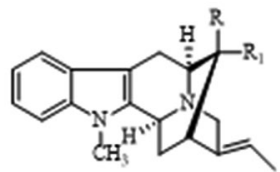

(9) Voachalotine: $\mathrm{R}=\mathrm{CO}_{2} \mathrm{CH}_{3} ; \mathrm{R}_{1}=\mathrm{CH}_{2} \mathrm{OH}$ (10) Affinisine: $\mathrm{R}=\mathrm{CH}_{2} \mathrm{OH} ; \mathrm{R}_{1}=\mathrm{H}$

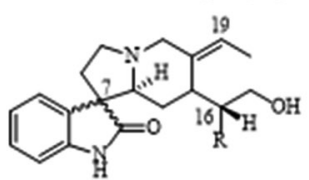

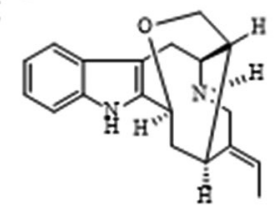

(18) $7(R)$-Geissoschizol oxindole: $R=H \quad$ (22) N(4)-Demethyltaberpsychine 19) 7(S)-Geissoschizol oxindole: $\mathrm{R}=\mathrm{H}$

(20) $7(\mathrm{R}), 16(\mathrm{R})-19(\mathrm{E})$-Isositsirikine oxindole: $\mathrm{R}=\mathrm{CO}_{2} \mathrm{CH}_{3}$

(21) 7(S), 16(R)-19(E)-Isositsirikine oxindole: $\mathrm{R}=\mathrm{CO}_{2} \mathrm{CH}_{3}$

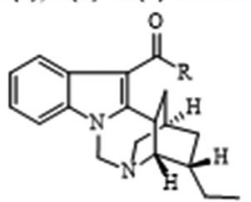

(23) Lirofoline $\mathrm{A}: \mathrm{R}=\mathrm{H}$ (24) Lirofoline $\mathrm{B}: \mathrm{R}=\mathrm{CH}_{2} \mathrm{OH}$

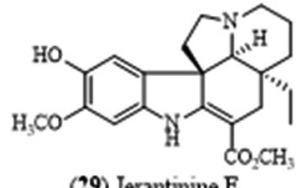

(29) Jerantinine $\mathrm{B}$

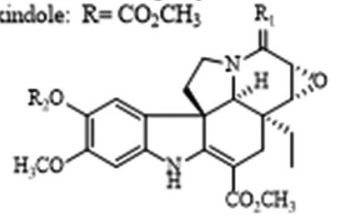

(26) Jerantinine $\mathrm{B}: \mathrm{R}_{1}=\mathrm{H}_{2}, \mathrm{R}_{2}=\mathrm{H}$ (28) Jerantinine $D: R_{1}=O, R_{2}=H$<smiles>COC(=O)C1=C2Nc3cc(OC)c(O)cc3[C@@]23CCN2CC[C@H]4OCC[C@@H]4[C@]23C1</smiles>

(30) Jerantinine F

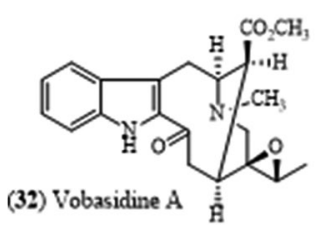

(32) Vobasidine $\mathrm{A}$

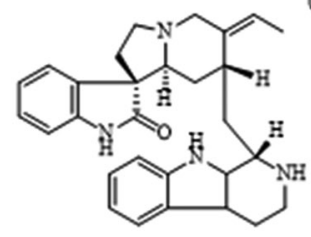

(38) Taipinisine

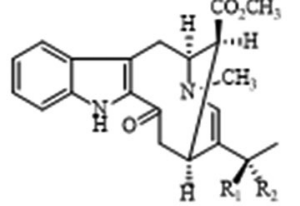

(33) Vobasidine $\mathrm{B}: \mathrm{R}=\mathrm{R}$ (35) Vobasidine $D: R_{1}, R_{2}=O$

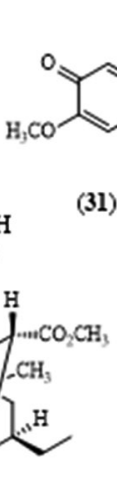

(34) Vobasidine $C$

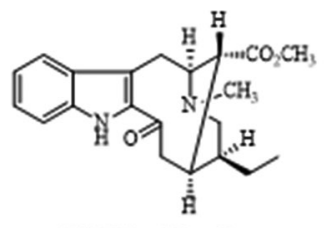

kaloids

(1-39) isolated from Tabernaemontana plants

lactate dehydrogenase in rats. In addition, the histopathological study also showed inactive on any abnormalities in the liver and kidney. From these results, $T$. coronaria extract can be used in indigenous system of medicine because this extract showed no acutely toxic to the rats. However, further long-term toxicological studies (chronic study) are needed to establish it as medicine for human consumption [15].

\section{Tabernaemontana corymbosa Roxb. ex Wall.}

This plant provided several novel molecular skeletons of indole alkaloids (Schemes 3-5) which have been shown to exhibit a wide array of biological activities. Lim and co-worker reported the isolation of novel monoterpene indole alkaloids from the stem bark extract of Malaysian T. corymbosa which were collected from a different part in Malaysian, including conolutinine (11) [16] and a mixture of (1'S, 2'S)- and (1'R, $\left.2^{\prime} \mathrm{R}\right)$-diastereomers of alkaloid-lignan conjugates, conoliferine (12) and isoconoliferine (13) [17]. The structure of 11 showed an unprecedented ring system incorporating a diazaspiro center and fused oxadiazepinetetrahydrofuran rings [16]. In addition, four novel natural products indole alkaloid-hydroxycinnamyl alcohol conjugates, conomicidines $\mathrm{A}$ and $B(14$ and 15$)$ and diastereomeric isoconomicidines A and B (16 and 17) [18], four tetracyclic oxindole alkaloids, $7(\mathrm{R})$ - and $7(\mathrm{~S})$-geissoschizol oxindole (18 and 19), 7(R), 16(R)- and 7(S), 16(R)-19(E)-isositsirikine oxindole (20 and 21), together with a new taberpsychine derivative, $\mathrm{N}(4)$-demethyltaberpsychine (22) [19], and two new pentacyclic indole alkaloids was possessed a novel rearranged ibogan ring system, lirofolines A and B (23 and 24) [20] were also isolated from this plant. Moreover, 


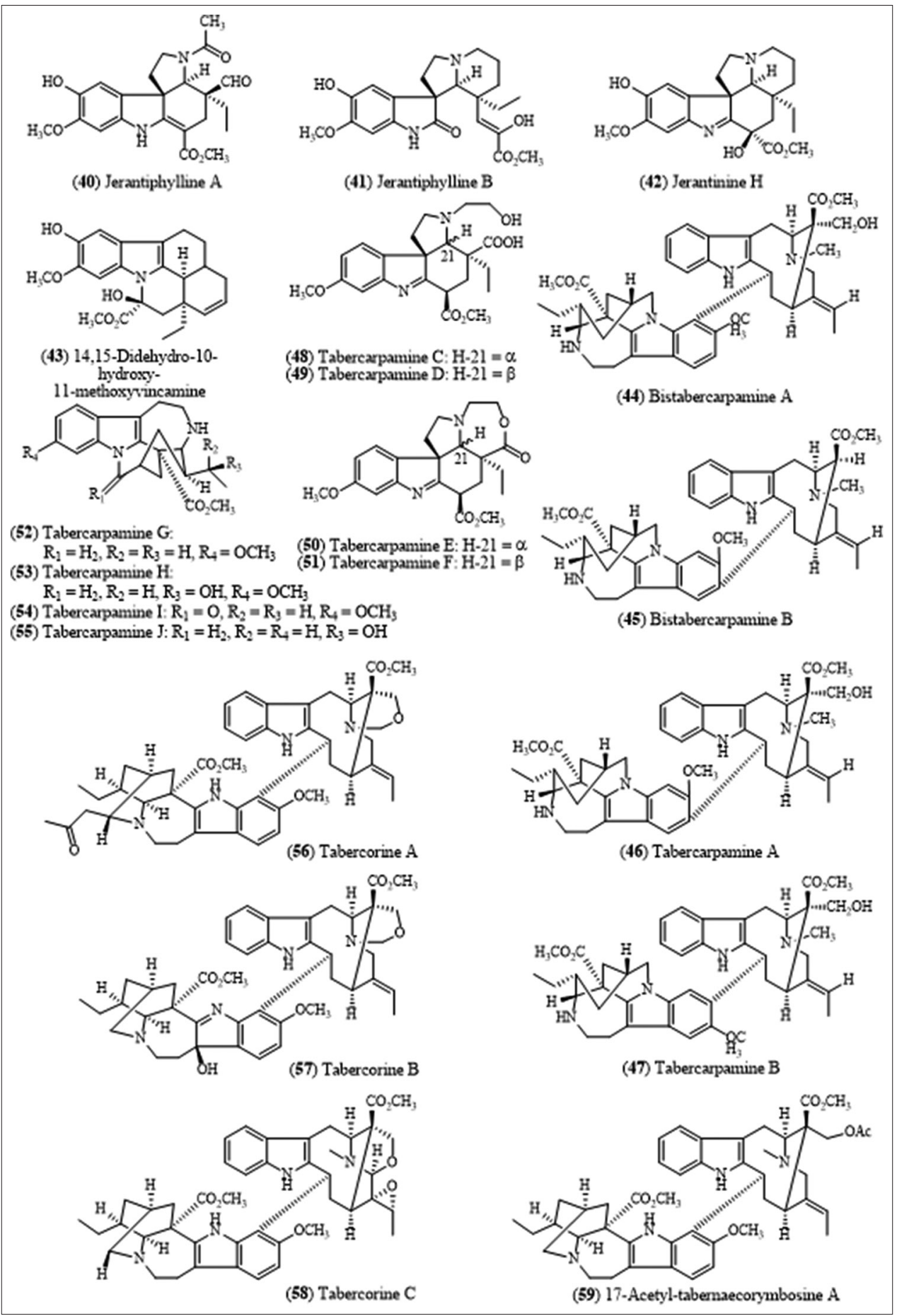

Scheme 4: Bioactive indole alkaloids (40-59) isolated from Tabernaemontana plants

these research groups reported that the isolation and purification of seven new cytotoxic Aspidosperma-type alkaloids, jerantinines A-G (25-31) against human $\mathrm{KB}$ cells $\left(\mathrm{IC}_{50}<1 \mu \mathrm{g} / \mathrm{mL}\right.$ ) [21]. In addition, the isolation of seven indole alkaloids (32-38) from the stem bark extract of Malaysian T. corymbosa which were collected near Taiping, Perak, Malaysia was reported by Sim et al. Two of the new vobasine alkaloids (32 and 34) showed appreciable cytotoxicity toward $\mathrm{KB}$ cells $\left(\mathrm{IC}_{50} \mathrm{ca}\right.$. $5.0 \mu \mathrm{g} / \mathrm{mL}$ ). The structure of the known Tabernaemontana alkaloid tronoharine (39) was revised based on newly acquired nuclear magnetic resonance (NMR) data, as well as X-ray diffraction analysis [22].

Moreover, Lim et al. were reported the isolation of two secotabersonine alkaloids, jerantiphyllines A and B (40 and 41) and a tabersonine hydroxyindolenine alkaloid, jerantinine $\mathrm{H}$ (42), from the leaves extract of the same plant species, but involving plant material collected from a different location and also reported vincamine alkaloid 43 from the leaves of this plant [8]. In 2014, the isolation of two novel dimeric monoterpene indole alkaloids, bistabercarpa-mines A (44) and B (45) possessing unprecedented bis-vobasinyl-chippiine-type skeleton from the leaves extract of T. corymbosa which were collected from Yunnan Province of China was reported Ma et al. In addition, bistabercarpamine A (44) showed moderate cell growth inhibitory activity against HepG-2 cells with $\mathrm{IC}_{50}$ of $38.14 \pm 1.1 \mu \mathrm{M}$ [23] and were also reported the isolation of ten indole alkaloids, tabercarpamines A-J (46-55) from the leaves extract of the same species. In addition, the all isolated compounds were evaluated for cytotoxic activity using 3-(4,5-dimethylthiazol-. 


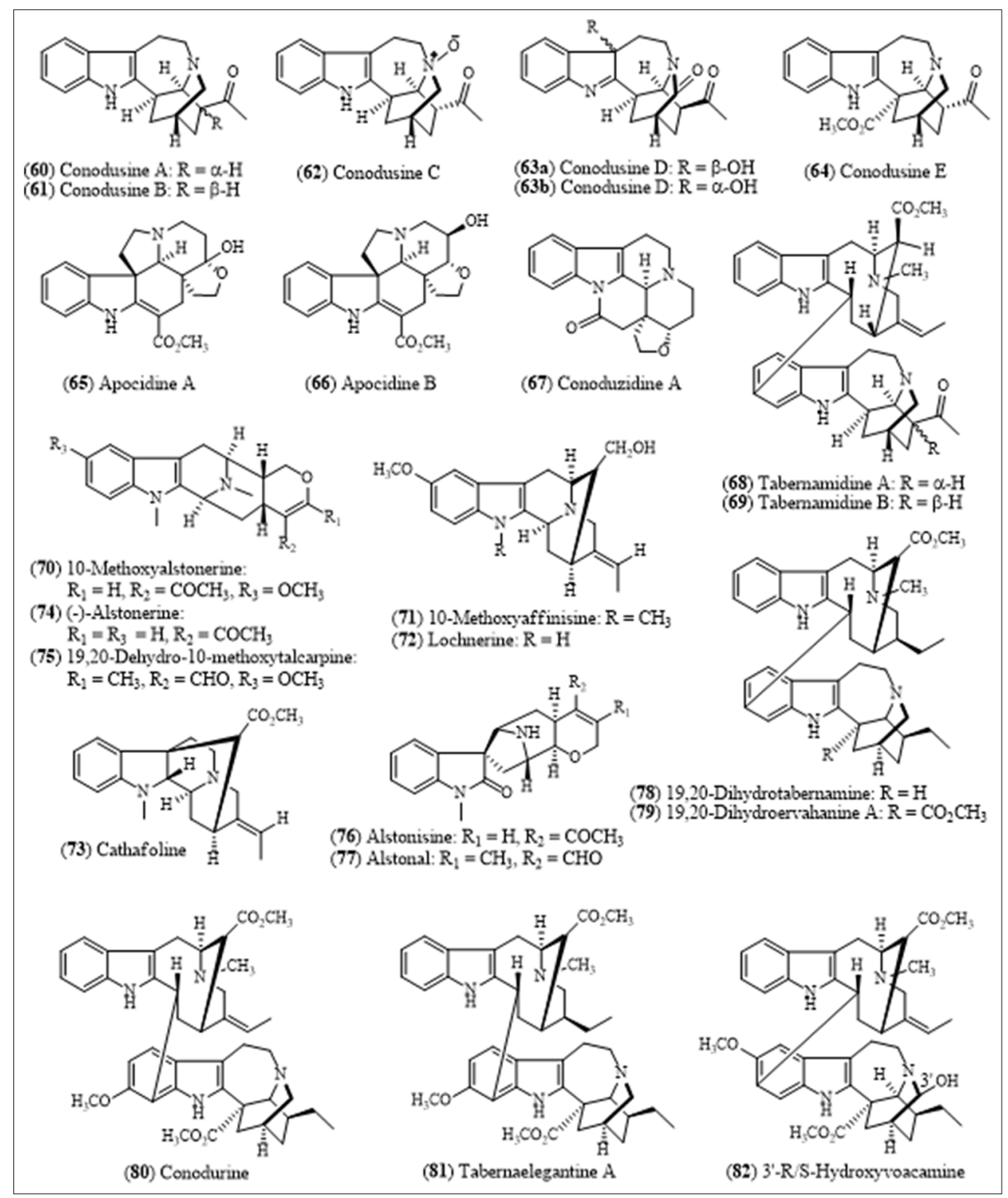

Scheme 5: Bioactive indole alkaloids (60-82) isolated from Tabernaemontana plants

2-yl)-2,5-diphenyl tetrazolium bromide assay against MCF-7, HepG2, and SMMC-7721 cell lines. The cytotoxicity results, alkaloid 47 showed significant inhibitory effects against all human cancer cell lines. Moreover, alkaloid 48 inhibited the proliferation of HepG2 cells by inducing apoptosis using the annexin-V/PI double-staining assay [24].

In addition, Zhang et al. reported the isolation and evaluation for cytotoxicity against various human cancer cell lines of three vobasinylibogan type bisindole, tabercorines A-C (56-58), together with 17-acetyltabernaecorymbosine A (59) from the twigs and leaves of $T$ /corymbosa. It was found that alkaloids 56 and 59 showed significant inhibitory effects with $\mathrm{IC}_{50}$ values comparable to those of cisplatin [25]. In the recently, Nge et al. reported the isolation and identification of eight monomeric $(60-67)$ and two dimeric $(68,69)$ indole alkaloids from the stem bark of Malayan T. corymbosa. The structure and absolute configurations of all new monoterpene indole alkaloids were completely determined based on spectroscopic data and X-ray diffraction analysis [26].

\section{Tabernaemontana crassa Benth.}

In 2010, Kuete et al. reported the toxicological activity of the hydroethanol extract from the stem bark of T. crassa (Apocynaceae). This extract showed no a dose-related effect in liver, lungs, and kidneys at $0.5 \mathrm{~g} / \mathrm{kg}$ body weight when the animals received the extract for 6 weeks daily. The acute toxicity of this plant extract indicated the medium lethal dose $\left(\mathrm{LD}_{50}\right)$ of $6.75 \mathrm{~g} / \mathrm{kg}$ body weight after treatment for $48 \mathrm{~h}$ and they showed no effected with body weight, serum ALP, alanine aminotransferase, total bilirubin, direct bilirubin, and creatinine ( $\mathrm{SCr}$ ) at the dose of $6 \mathrm{~g} / \mathrm{kg}$. The results indicate that the stem bark extract of $T$. crassa showed no toxic with animal in several conditions and can be a promising source of new natural product drug [27].

\section{Tabernaemontana dichotoma Roxb. ex Wall.}

In 2013, Zaima et al. reported the screening of medicinal plants targeting vasorelaxant activity. It was found that the methanol extract from T. dichotoma bark showed vasorelaxant activity on rat aorta. After that, this plant extract was isolated to give eight indole alkaloids (Scheme 5) including 10-methoxyalstonerine (70), 10-methoxyaffinisine (71), lochnerine (72), cathafoline (73), (-)-alstonerine (74), 19,20-dehydro-10-methoxytalcarpine (75), alstonisine (76), and alstonal (77). Among of them, sarpagine type (71 and 72), akuammiline type (73), and macroline oxindole type (76 and 77) showed potent vasorelaxant activity. Furthermore, alkaloids 71 and 76 attribute to the inhibitory effect of voltage-dependent $\mathrm{Ca}^{2+}$ channel and receptor-operated $\mathrm{Ca}^{2+}$ channel. In addition, the major compound 


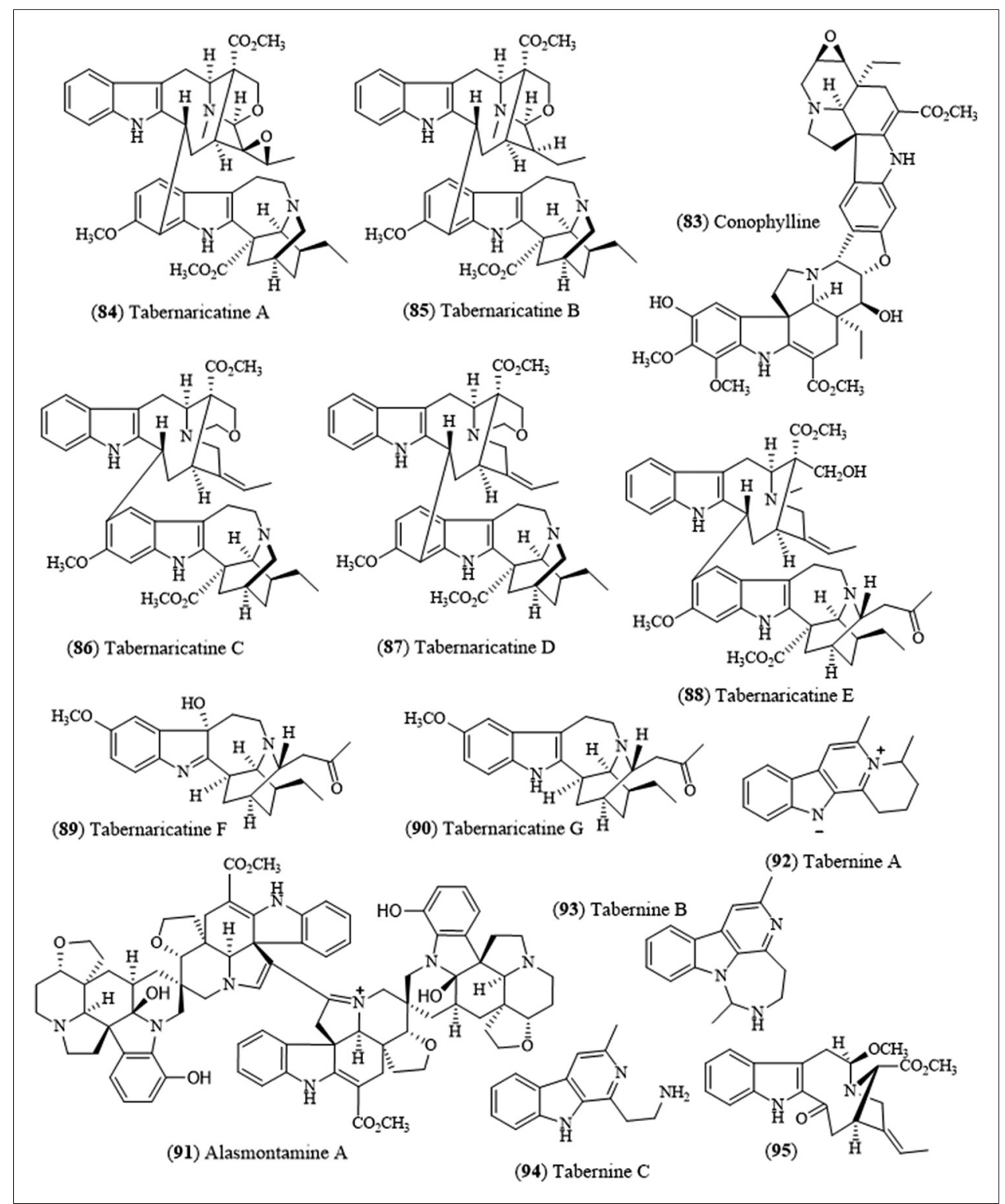

Scheme 6: Bioactive indole alkaloids (83-95) isolated from Tabernaemontana plants

(71) from T. dichotoma bark extract showed hypotensive effect on normotensive rats in vivo [28].

\section{Tabernaemontana divaricata (L.) R. Br.}

Acetylcholinesterase inhibitors (AChE-Is) are the current pharmacotherapy to use for Alzheimer's disease (AD). In 2006, Ingkaninan et al. reported the bioassay-guided fractionation of the different parts of $T$. divaricata (flowers, leaves, stems, and roots) on AChE activity using the Ellman's colorimetric method. It was found that the stem $(94.72 \pm 2.09 \%)$ and root $(99.72 \pm 0.26 \%)$ extracts were showed high inhibitory activity while the leaves and flower extracts showed lower activity. From these results led to the isolation of four AChE inhibitors (Scheme 5) including two new bisindole alkaloids, 19,20-dihydrotabernamine (78) and 19,20-dihydro-ervahanine A (79) together with two known bisindole alkaloids, conodurine (80), and tabernaelegantine A (81) from the root extract of this plant [29]. The next year, this group was also reported in vivo the evaluation of AChE inhibitory effects and Fos expression on neuronal activity in the cerebral cortex of the ethanolic extracts from roots of T. divaricata. This extracts showed strong the neuronal activity with the enhancement of Fos expression and AChE inhibitory effects in the cerebral cortex [30]. Moreover, this group was also reported in 2010 for the effects of
T. divaricate root extract on $\beta$-amyloid25-35 peptides-induced cognitive deficits in mice. After mice were treated with root extract, it was found that this extract improved the memory impairment and attenuated the brain levels of AChE activity induced by A $325-35$ peptides [31]. On the other hand for AD treatment, Chaiyana et al. reported that the alkaloidal extract from T. divaricata stem was showed enhancing the acetylcholine level in Alzheimer's patients. From these results, they reported the isolation of 3 '- $R / S$-hydroxyvoacamine (82) which showed noncompetitive inhibitor against AChE with an $\mathrm{IC}_{50}$ value of $7.00 \pm 1.99 \mu \mathrm{M}[32,33]$.

For cytotoxic activity of T. divaricata, Thind et al. reported to study on cytotoxic activities against HCT-15 (Colon), HT-29 (colon), 502713 (colon), MCF-7 (breast), PC-3 (prostrate) cell lines and evaluated the mechanism of cytotoxicity including hydroxyl radical scavenging and topoisomerase inhibitory activities of the leaves extracts (hexane, chloroform, EA and methanol) of this plant. It was observed that the EA extract was effective against only one colon cell line (502713), whereas the chloroform extract was effective against all the three colon cancer cell lines. Moreover, the EA extract also showed selectively inhibition of topo II in topoisomerase II relaxation assay [34]. In 2013, Zhang et al. reported to study of conophylline (83), is a bis-indole alkaloid (Scheme 


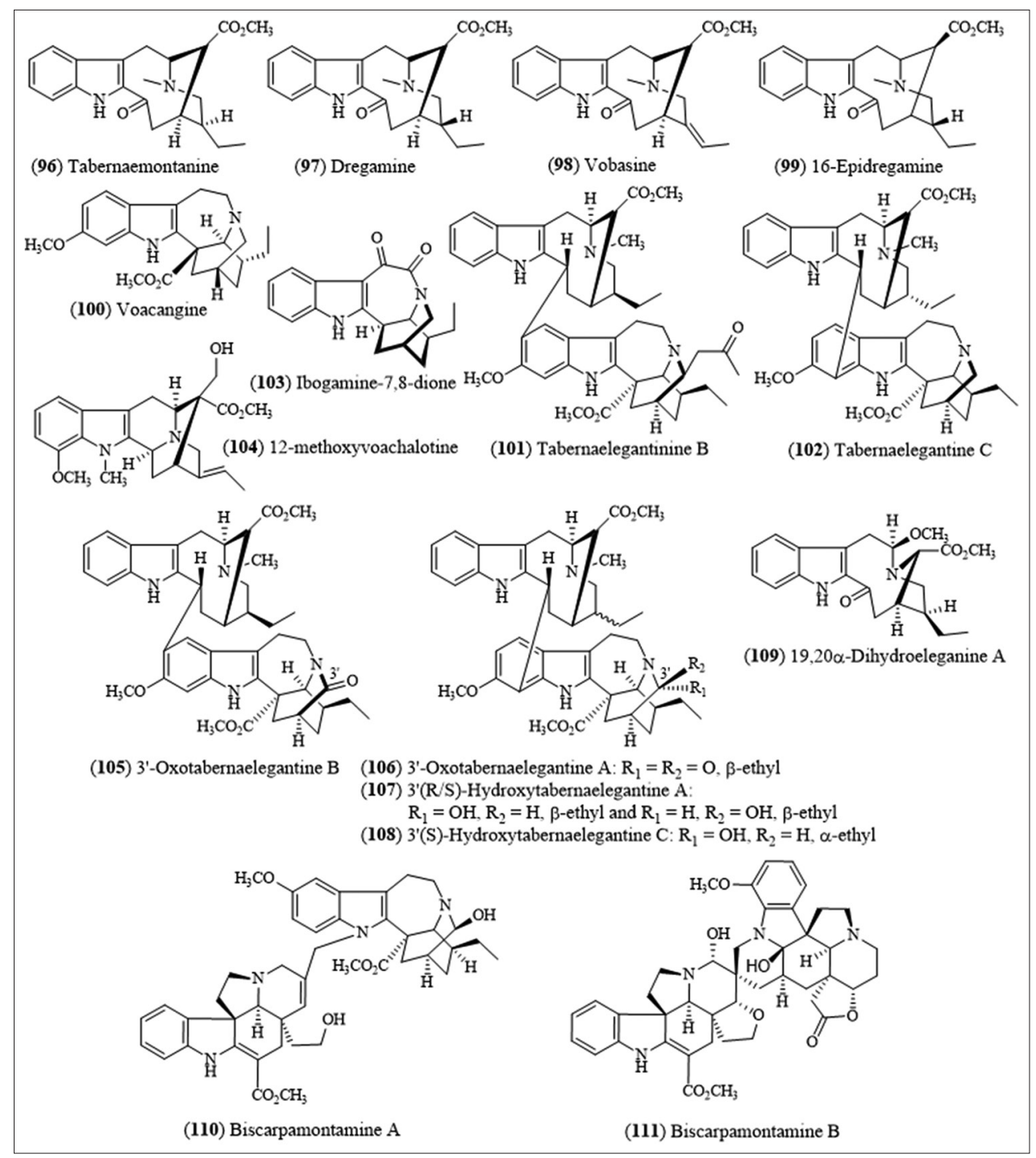

Scheme 7: Bioactive indole alkaloids (96-111) isolated from Tabernaemontana plants

6) consisting of two pentacyclic aspidosperma skeletons, isolated from T. divaricata, which has been found to induce b-cell differentiation in rat pancreatic acinar carcinoma cells and in cultured rat pancreatic tissue [35]. In the same year, Bao et al. reported the isolation of five new cytotoxic vobasinyl-ibogan-type bisindole alkaloids (Scheme 6), tabernaricatines A-E (84-88), two new monomers, tabernaricatines F and G (89 and 90), and 24 known indole alkaloids were isolated from the aerial parts of T. divaricata [36]. In 2012, two research groups including Jain et al. and Mukhram et al. reported to evaluate the antifertility effect of leaves and flowers extracts of $T$. divaricata in male rats and female albino mice. In the male rat results, the extracts produced dose-related effect on reproduction. The effect may have an inhibitory influence on gonadotropin release which may be responsible for the decline in testosterone production, leading to change in spermatogenesis. For female albino mice, disturbance on the estradiol secretion with significant decrease during estrous stage of the cycle observed with the extract treatment may be due to impairment in the release of luteinizing hormone and follicle stimulating hormone causing hormonal imbalance. These researches could also suggest the anti-fertility effect of leaves and flowers extracts of T. divaricata [3739]. In 2013, Jain et al. reported the in vivo anti-inflammatory activity of T. divaricata leaves extract on male albino mice. The hexane fraction which is very rich of flavonoid compound showed a very high antiinflammatory activity. This fraction was also active than positive drug indomethacin [40].
Tabernaemontana elegans Staph.

In 2009, Hirasawa et al. reported the isolation a novel tetrakis monoterpene indole alkaloid 91, namely, alasmontamine A, from the leaves of this plant and this novel compound exhibited moderate cell growth activity against HL-60 cells [7]. The same year, Mansoor et al. reported the isolation of three novel $\beta$-carboline indole alkaloids (92-94) from the $\mathrm{MeOH}$ extract of the leaves of T. elegans (Scheme 6) and these compounds were evaluated for their ability to modulate multidrug resistance in mouse lymphoma cell lines [41]. Moreover, this group was also reported the isolation a novel (95) and three known monoterpene indole alkaloids (96-98) from the methanol extract of T. elegans leaves. The isolated alkaloids were evaluated for their apoptosis induction activity in human hepatoma HuH-7 cells. The monoterpene indole alkaloids, 96 and 98, showed the most promising apoptosis induction profile in HuH-7 cells [42]. Moreover, this group reported the isolation of six alkaloids (Schemes 7) including four monomeric indoles (96-97 and 99-100) and two bisindoles (101 and 102) alkaloids from the methanolic extract of T. elegans roots. All isolated alkaloids were evaluated for in vitro cytotoxicity against HCT116 human colon carcinoma cell by the 3-(4,5-dimethylthiazol-2-yl)-5-(3-carboxymethoxyphenyl)-2-(4sulfophenyl)- $2 H$-tetra-zolium, inner salt metabolism assay. Among the tested compound, two bisindole alkaloids were found to be cytotoxic to HTC116 cell at $20 \mu \mathrm{M}$, with compound 91 being more cytotoxic than the positive control 5-fluorouracil (5-FU), at a similar dose. Further, general caspase-3-like activity was increased in cells exposed to compounds 101 
and 102, corroborating the nuclear morphology evaluation assay [43]. In 2011, Luo et al. reported the antimycobacterial evaluation of selected medicinal plants traditionally used in Mozambique. From the results, the EA extract of T. elegans showed strong activity against Mycobacterium tuberculosis $\mathrm{H} 37 \mathrm{Rv}$ at MIC value of $15.6 \mu \mathrm{g} / \mathrm{mL}$ and the prominent compounds were identified as indole alkaloids [44]. Moreover, the next year, Pallant, Cromarty, and Steenkamp reported the isolation and identification the fraction responsible for the antimicrobial activity in T. elegans roots extract. It was found that the GC-MS analysis identified the indole alkaloids, dregamine (97) and voacangine (100), as major components which were showed good antibacterial activity including Gram-positive bacteria and Mycobacterium species, with MIC values in the range of $64-256 \mu \mathrm{g} / \mathrm{mL}[45]$.

\section{Tabernaemontana hystrix Steud.}

In 2010, Souza et al. reported the isolation of two new monoterpene alkaloids, ibogamine-7,8-dione (103) and 12-methoxyvoachalotine (104) of the $\mathrm{CH}_{2} \mathrm{Cl}_{2}$ extract from the root bark of T. hystrix (Scheme 7). The structures of all compounds were elucidated on the basis of spectroscopic data analyses, mainly ${ }^{1} \mathrm{H}-$ and ${ }^{13} \mathrm{C}$-NMR, including twodimensional experiments $\left({ }^{1} \mathrm{H},{ }^{1} \mathrm{H}-\mathrm{COSY}, \mathrm{HMBC}\right.$, and $\left.\mathrm{HMQC}\right)$ [46].

\section{Tabernaemontana sessilifolia (Baker)}

In 2012, Girardot et al. reported the isolation of four vobasinyl-iboga bisindole (105-108) and one 2-acyl monomeric indole (109) alkaloids from the stem bark of T. sessilifolia (Scheme 7). All isolated alkaloids were evaluated for antiplasmodial activity against the chloroquineresistant strain FcB1 of Plasmodium falciparum, and cytotoxicity against the human lung cell line MRC-5 and the rat skeletal muscle cell line L-6. The alkaloid, namely, 3'-oxotabernaelegantine A (106) exhibited antiplasmodial activity $\left(\mathrm{IC}_{50}=4.4 \mu \mathrm{M}\right)$ associated with nonsignificant cytotoxicity (selectivity index of 48). Tabernaelegantine B (101) displayed the highest cytotoxicity with $\mathrm{IC}_{50}$ values of 0.47 and $0.42 \mu \mathrm{M}$ on MRC-5 and L-6 cells, respectively [47].

\section{Tabernaemontana sphaerocarpa Blume}

In 2009, Zaima et al. reported the isolation of biscarpamontamine A (110), possessing an aspidosperma-iboga-type skeleton, and biscarpamontamine B (111), having an aspidosperma-aspidospermatype skeleton, from the stems of T. sphaerocarpa (Scheme 7). Bis-indole alkaloid 111 showed potent cytotoxicity against various human cancer cell lines, including human blood premyelocytic Leukemia (HL60), multiple myeloma (RPMI8226), non-small cell lung carcinoma (NCI-H226), human colon cancer (HCT116), and human breast adenocarcinoma (MCF-7) cells with $\mathrm{IC}_{50}$ value in the range of 0.5-1.9 $\mu \mathrm{M}$ [48].

\section{CONCLUSION}

Recent studies have provided evidence that natural-derived bioactive monoterpene indole alkaloids play a vital role in human health and nutrition as well as disease prevention. They offer a diverse range of structurally distinctive bioactive molecules have been used as a major source of innovative and effective therapeutic agents. Furthermore, the biological screening of active monoterpene indole alkaloids, using a wide variety of scientific tools and the interactive collaboration of experts in diverse scientific disciplines will become research hotspot, providing new and essential health-care opportunities.

\section{ACKNOWLEDGMENT}

I would like to thank the Research Grant of Burapha University through National Research Council of Thailand (Grant no. 80/2558), Department of Chemistry and Center of Excellence for Innovation in Chemistry (PERCH-CIC), Faculty of Science, Burapha University for the financial support.

\section{REFERENCES}

1. Salim AA, Chin YW, Kinghorn AD. Chapter I: Drug discovery from plants. In: Ramawat KG, Merillon JM, editors. Bioactive Molecules and Medicinal Plants. New York: Springer; 2008. p. 1-24.
2. Boligon AA, Freitas RB, Brum TF, Piana M, Belke BV, Rocha JB, et al. Phytochemical constituents and in vitro antioxidant capacity of Tabernaemontana catharinensis A. DC. Free Radic Antioxid 2013;3:77-80

3. Qui S, Sun H, Zhang AH, Xu HY, Yan GL, Hun Y, et al. Natural alkaloids: Basic aspects, biological roles, and future perspectives. Chin J Nat Med 2014;12:401-6.

4. Beek TA, Verpoorte R, Svendsen AB, Leeuwenberg AJ, Bisset NG. Tabernaemontana L. (Apocynaceae): A review of its taxonomy, phytochemistry, ethnobotany and pharmacology. J Ethnopharmacol 1984;10:1-156.

5. Kam TS. In: PitorAlkaloids: Chemical and Biological Perspectives. Pergamon: Amsterdam; 1999. p. 285-435.

6. Jiang Y, Li BT. Flora China (Zhongguo Zhiwu Zhi). Beijing: Science Press; 1997. p. 98-9.

7. Hirasawa Y, Miyama S, Hosoya T, Koyama K, Rahman A, Kusumawati I, et al. Alasmontamine A, A first tetrakis monoterpene indole alkaloid from Tabernaemontana elegans. Org Lett 2009;11:5718-21.

8. Lim KH, Thomas NF, Abdullah Z, KAm TS. Seco-tabersonine alkaloids from Tabernaemontana corymbosa. Phytochemistry 2009;70:424-9.

9. Guo LL, He HP, Di YT, Li SF, Cheng YY Yang W, et al. Indole alkaloids from Ervatamia chinensis. Phytochemistry 2012;74:140-5.

10. O'Connor SE, Maresh JJ. Chemistry and biology of monoterpene indole alkaloid biosynthesis. Nat Prod Rep 2006;23:532-47.

11. Andrade MT, Lima JA, Pinto AC, Rezende CM, Carvalho MP, Epifanio RA. Indole alkaloids from Tabernaemontana australis (Müell. Arg) miers that inhibit acetylcholinesterase enzyme. Bioorg Med Chem 2005; 13:4092-5

12. Soares DC, Pereira CG, Meireles MA, Saraiva EM. Leishmanicidal activity of a supercritical fluid fraction obtained from Tabernaemontana catharinensis. Parasitol Int 2007;56:135-9.

13. Boligon AA, Piana M, Kubica TF, Mario DN, Dalmolin TV, Bonez PC, et al. HPLC analysis and antimicrobial, antimycobacterial and antiviral activities of Tabernaemontana catharinensis A. DC. J App Biomed 2015;13:7-18.

14. Marie-Magdeleine C, Mahieu M, D’Alexis S, Philibert L, Archimede H. In vitro effects of Tabernaemontana citrifolia extracts on Haemonchus contortus. Res Vet Sci 2010;89:88-92.

15. Poornima K, Krishnan R, Aswathi KV, Gopalakrishnan VK. Toxicological evaluation of ethanolic extract of Tabernaemontana coronaria (L) R. Br. Asian Pac J Trop Dis 2012;2:S679-S684.

16. Lim KH, Etoh T, Hayashi M, Komiyama K, Kam TS. Conolutinine, a hexacyclic indole alkaloid with a novel ring system incorporating a diazaspiro center and fused Oxadiazepine-tetrahydrofuran rings. Tetrahedron Lett 2009;50:752-4.

17. Lim KH, Kam TS. Conoliferine and isoconoliferine, structurally novel alkaloid-lignan conjugates from Tabernaemontana corymbosa. Tetrahedron Lett 2009;50:3756-9.

18. Lim KH, Kam TS. Conomicidines A and B, unusual alkaloidhydroxycinnamyl alcohol conjugates from Tabernaemontana corymbosa. Helv Chim Acta 2009;92:1895-902.

19. Lim KH, Sim KM, Tan GH, Kam TS. Four tetracyclic oxindole alkaloids and a taberpsychine derivative from a Malayan Tabernaemontana. Phytochemistry 2009;70:1182-6.

20. Low YY, Lim KH, Choo YM, Pang HS, Etoh T, Hayashi M, et al. Structure, biological activity, and a biomimetic partial synthesis of the lirofolines, novel pentacylic indole alkaloids from Tabernaemontana. Tetrahedron Lett 2010;51:269-72.

21. Lim KH, Hiraku O, Komiyama K, Kam TS. Jerantinines A-G, Cytotoxic Aspidosperma alkaloids from Tabernaemontana corymbosa. J Nat Prod 2008;71:1591-4.

22. Sim DS, Chong KW, Nge CE, Low YY, Sim KS, Kam TS. Cytotoxic vobasine, tacaman, and corynanthe-tryptamine bisindole alkaloids from Tabernaemontana and structure revision of tronoharine. J Nat Prod 2014:77:2504-12.

23. Ma K, Wang JS, Luo J, Yang MH, Yao HQ, Sun HB, et al. Bistabercarpamines A and B, first vobasinyl-chippiine-type bisindole alkaloid from Tabernaemontana corymbosa. Tetrahedron Lett 2014;55:101-4.

24. Ma K, Wang JS, Luo J, Yang MH, Kong L. Tabercarpamines A-J, apoptosis-inducing indole alkaloids from the leaves of Tabernaemontana corymbosa. J Nat Prod 2014;77:1156-63.

25. Zhang Y, Guo L, Yang G, Guo F, Di Y, Li S, et al. New vobasinylibogan type bisindole alkaloids from Tabernaemontana corymbosa. Fitoterapia 2015;100:150-5.

26. Nge CE, Chong KW, Thomas NF, Lim SH, Low YY, Kam TS. Ibogan, 
Aspidosperman, vincamine and bisindole alkaloids from a Malayan Tabernaemontana corymbosa: Iboga alkaloids with C-20 $\alpha$ substitution. J Nat Prod 2016;79:1388-99.

27. Kuete V, Manfouob RN, Beng VP. Toxicological evaluation of the hydroethanol extract of Tabernaemontana crassa (Apocynaceae) stems bark. J Ethnopharmacol 2010;130:470-6.

28. Zaima K, Koga I, Iwasawa N, Hosoya T, Hirasawa Y, Kaneda T, et al. Vasorelaxant activity of indole alkaloids from Tabernaemontana dichotoma. J Nat Med 2013;67:9-16.

29. Ingkaninan K, Changwijit K, Suwanborirux K. Vobasinyl-iboga bisindole alkaloids, potent acetylcholinesterase inhibitors from Tabernaemontana divaricata root. J Pharm Pharmacol 2006;58:847-52.

30. Chattipakorn S, Pongpanparadorn A, Pratchayasakul W, Pongchaidacha A, Ingkaninan K, Chattipakorn N. Tabernaemontana divaricata extract inhibits neuronal acetylcholinesterase activity in rats. J Ethnopharmacol 2007;110:61-8.

31. Nakdook W, Khongsombat O, Taepavarapruk P, Taepavarapruk N, Ingkaninan $\mathrm{K}$. The effects of Tabernaemontana divaricata root extract on amyloid $\beta$-peptide25-35 peptides induced cognitive deficits in mice. J Ethnopharmacol 2010;130:122-6.

32. Chaiyana W, Rades T, Okonogi S. Characterization and in vitro permeation study of microemulsions and liquid crystalline systems containing the anticholinesterase alkaloidal extract from Tabernaemontana divaricate. Inter J Pharmaceut 2013;452:201-10.

33. Chaiyana W, Schripsema J, Ingkaninan K, Okonoqi S. 3'-R/Shydroxyvoacamine, a potent acetylcholinesterase inhibitor from Tabernaemontana divaricate. Phytomedicine 2013;20:543-8.

34. Thind TS, Agrawal SK, Saxena AK, Arora S. Studies on cytotoxic, hydroxyl radical scavenging and topoisomerase inhibitory activities of extracts of Tabernaemontana divaricata (L.) R.Br. ex roem. and schult. Food Chem Toxicol 2008:46:2922-7.

35. Zhang HR, Li D, Cao H, Lu X, Chu YK, Bai YF, et al. Conophylline promotes the proliferation of immortalized mesenchymal stem cells derived from fetal porcine pancreas (iPMSCs). $=\mathrm{J}$ Integ Agric 2013;12:678-86

36. Bao MF, Yan JM, Cheng GG, Li XY, Liu YP, Li Y, et al. Cytotoxic indole alkaloids from Tabernaemontana divaricate. J Nat Prod 2013;76:1406-12.

37. Jain S, Jain A, Paliwal P, Solanki SS. Antifertility effect of chronically administered Tabernaemontana divaricata leaf extract on male rats. Asia Pac J Trop Med 2012;5:547-51.

38. Jain S, Jain DK, Balekar N, Jain A. Antifertility effect of chronically administered Tabernaemontana divaricata leaf extract on female albino mice. Asia Pac J Trop Dis 2012;2:S159-62.

39. Mukhram MA, Shivakumar H, Viswanatha GL, Rajesh S. Anti-fertility effect of flower extracts of Tabernaemontana divaricata in rats. Chin J Nat Med 2012;10:58-62.

40. Jain S, Sharma P, Ghule S, Jain A, Jain N. In vivo anti-inflammatory activity of Tabernaemontana divaricata leaf extract on male albino mice. Chin J Nat Med 2013;11:472-6.

41. Mansoor TA, Ramalhete C, Molnar J, Mulhovo S, Ferreira MJ. Tabernines A-C, beta-carbolines from the leaves of Tabernaemontana elegans. J Nat Prod 2009;72:1147-50.

42. Mansoor TA, Ramalho RM, Mulhovo S, Rodriques CM, Ferreira MJ. Induction of apoptosis in $\mathrm{HuH}-7$ cancer cells by monoterpene and betacarboline indole alkaloids isolated from the leaves of Tabernaemontana elegans. Bioorg Med Chem Lett 2009;19:4255-8.

43. Mansoor TA, Barralho PM, Dewanjee S, Mulhovo S, Rodriques CM, Ferreira MJ. Monoterpene bisindole alkaloids, from the African medicinal plant Tabernaemontana elegans, induce apoptosis in HCT116 human colon carcinoma cells. J Ethnopharmacol 2013;49:463-70.

44. Luo X, Pires D, Ainsa JA, Gracia B, Mulhovo S, Duarte A, et al. Antimycobacterial evaluation and preliminary phytochemical investigation of selected medicinal plant traditionally used in Mozambique. J Ethnopharmacol 2011;137:114-20.

45. Pallant CA, Cromarty AD, Steenkamp V. Effect of an alkaloidal fraction of Tabernaemontana elegans (Stapf.) on selected micro-organisms. J Ethnopharmacol 2012;140:398-404

46. Souza JJ, Mathias L, Braz-Filho R, Vieira IJ. Two new indole alkaloids from Tabernaemontana hystrix Steud. (Apocynaceae). Helv Chem Acta 2010;93:422-9.

47. Girardot M, Deregnaucourt C, Deville A, Dubost L, Joyeau R, Allorqe L, et al. Indole alkaloids from Muntafara sessilifolia with antiplasmodial and cytotoxic activities. Phytochemistry 2012;73:65-73

48. Zaima K, Hirata T, Hosoya T, Hirasawa Y, Koyama K, Rahman A, et al. Biscarpamontamines A and B, an Aspidosperma-Iboga bisindole alkaloid and an Aspidosperma aspidosperma bisindole alkaloid, from Tabernaemontana sphaerocarpa. J Nat Prod 2009;72:1686-90. 